\title{
Psycholinguistic Mechanisms of Understanding Contemporary Poetry by Future Philologists*
}

\section{Психолінгвістичні механізми розуміння сучасної поезії майбутніми філологами **}

\section{Nataliia Mykhalchuk ${ }^{1}$ \\ Dr. Sc. in Psychology, \\ Professor}

\author{
Наталія Михальчук ${ }^{1}$ \\ доктор психологічних наук, \\ професор
}

\author{
E-mail: Natasha1273@ukr.net \\ https://orcid.org/0000-0003-0492-9450 \\ Researcher ID: A-9440-2019 \\ Scopus ID: 57214227898
}

Ernest Ivashkevych ${ }^{1}$

Ph.D. in Psychology,

Assistant, Translator
Ернест Івашкевич ${ }^{1}$

кандидат психологічних наук, старший викладач, перекладач

E-mail: erikguetta@mail.ru https://orcid.org/0000-0001-7219-1086

Researcher ID: F-3865-2019

Inna Nohachevska ${ }^{1}$

Ph.D. in Psychology, Assistant Professor
Інна Ногачевська ${ }^{1}$

кандидат психологічних наук, доцент

E-mail: innatella@gmail.com https://orcid.org/0000-0002-1489-6878

Researcher ID: AAL-7233-2021

\footnotetext{
* This research was funded by the Ministry of Education and Science of Ukraine, RN 0118 U003098

** Дослідження виконане за фінансової підтримки Міністерства освіти і науки України, реєстраційний номер RN $0118 \mathrm{U} 003098$
} 
Alexander Nabochuk ${ }^{2}$

Ph.D. in Psychology
Олександр Набочук

кандидат психологічних наук

E-mail: nab_ol@ukr.net

https://orcid.org/0000-0002-1448-7687

Researcher ID: AAE-4773-2021

\section{Oksana Voitenko ${ }^{3}$}

Magister of Psychology, Assistant
Оксана Войтенко

магістр психології, асистент

E-mail: oxyvoyt@gmail.com

https://orcid.org/0000-0001-6299-5734

${ }^{1}$ Rivne State University of the

Humanities (Ukraine)

12, Stepan Bandera Str., Rivne,

Ukraine, 33000

${ }^{2}$ Rivne Regional Council (Ukraine)

$\triangle 1$, Prosvita Square, Rivne, Ukraine, 33000

${ }^{3}$ Університет Григорія Сковороди в Переяславі (Україна)

$\triangle$ вул. Сухомлинського, 30, м. Переяслав, Україна, 08401
${ }^{1}$ Рівненський державний гуманітарний університет (Україна)

$\checkmark$ вул. Степана Бандери, 12, м. Рівне, Україна, 33000

${ }^{2}$ Рівненська обласна рада (Украӥна) майдан Просвіти 1, м. Рівне, Україна, 33000

${ }^{3}$ Hryhorii Skovoroda University in Pereiaslav (Ukraine)

30, Sukhomlinsky Str., Pereiaslav, Ukraine, 08401

Original manuscript received December 12, 2020

Revised manuscript accepted September 12, 2021

\begin{abstract}
The purpose of the article is to conduct the empirical study of understanding contemporary poetry by future philologists, which helps us to distinguish psycholinguistic mechanisms of such understanding.

The methods of the research. The research was carried out using a sample method (using a questionnaire developed by us (Mykhalchuk, Ivashkevych \& Nabochuk, 2020). This questionnaire we use to assess the psychological specifics of understanding of contemporary poetry by future philologists. In order to establish the peculiarities of the content of the associative series of the word "poetry", we organized an associative experiment. Also we used the method of annotated reading (Illyashenko, 1980). The application of this technique involved solving the following tasks: (1) to develop the criteria to understand poetry for students; (2) to determine the levels of understanding of future philologists of poetic texts.
\end{abstract}


The results of the research. We single out some special psycholinguistic mechanisms of understanding of poetic texts by students-philologists, such as: (1). The mechanism of actualization of "emotions of form". (2). The mechanism of harmonization of meaning. (3). The mechanism of amplification of poetry. (4). The mechanism of acquiring aesthetic experience. We proved, that the subject of understanding is an active communicative person with multifaceted personal qualities. The subjective component of understanding is specified in two main groups of factors: (1) the factor of the activity of the understanding the subject, generalized in target conditions of understanding; (2) the factor of individual-personal conditionality of understanding: the assessment by the subject of understanding of his/her own moral, volitional, emotional-communicative qualities, personal aggression, a tendency to reflection, etc.

Conclusions. The success of improving readers' perception and understanding of the poetry depends on the activation of the latter. Readers focus more on direct intentions than on their own feelings and ideas about poetry, although the latter determines their different perceptions. The development of the perception and understanding of the poetic form of the reader is due to the realization of the increasing complex of emotional connections of the semantic elements of the text, and emotionality is one of the main criteria for assessing poetry.

Key words: psycholinguistic mechanisms of understanding, "emotions of form", amplification of poetry, acquiring aesthetic experience, the subjective component of understanding, emotional-communicative qualities, a tendency to reflection.

\section{Introduction}

There are two most important aspects in the phenomenon of understanding: (1) in a case we provide a research of understanding as a mental process and it is necessary to determine the relationships between the understanding and cognition, thinking and knowledge. In such a way it is possible to establish how organize the process of cognition of the subject and to supplement mental actions and their generate meaning (Hamedi \& Pishghadam, 2021); (2) it is important to identify the structure of personal attitudes of the subject as a component of the functional mechanism of social thinking, which amplifies understanding (Engle, 2002). Thus, scientists (Astle \& Scerif, 2011; Dale \& Duran, 2011) found the dominant signs of understanding: in a case of understanding anything we always go beyond clear facts, include them into more broader context; if we'd like to understand we have to correlate what is clear with our notions of what is right, that is, to compare these facts it's important what we understand with all general 
aspects of the subject. Thus, the researchers consider understanding as a process and a result of generating meaning (Berninger \& Abbott, 2010; El-Zawawy, 2021). In such a way the meaning is manifested in the personal, cognitive and emotional aspects to the object of understanding (Wong, 2021). The authors consider knowledge to be psychological preconditions and the basis of understanding (Greco et al., 2020).

To understand the subject of a recognizable object requires four conditions of understanding: purposeful ones (correspondence of the understandable of the goals of the person who understands), mnemonic conditions (presence in the memory of previous knowledge of the person who understands), empathic ones (personal attitude to the partner of communication) and person's compliance because of some way of communication (Mykhalchuk \& Bihunova, 2019; Shiva Ram, Bhardwaj \& Phani Krishna, 2017).

Some scientists (Alderson, Nieminen \& Huhta, 2016) define understanding as the integral part of the process of cognition. In such a way F.A. Conners (2009) considers it as a multifaceted, complex phenomenon, which includes: the ability to understand anything; the process itself, when the person understands how to penetrate into the essence of certain objects; the state of consciousness of the individual, revealing the essence; the result of this process, including those judgments, conclusions, concepts, views that are explicit for the person as a result of his/her understanding of certain objects.

Understanding is always experienced by the person (Arrington et al., 2014). His/her emotionality is largely actualized in a case when the understanding acquires some expanded character, turns into a search for truth (Drigas \& Karyotaki, 2017). According to Adachi and Willoughby (2015), understanding is assessed in terms of its truth (because of compliance of these results with the objective reality). True understanding always has a certain degree of its realization, which is characterized by considerable depth, completeness, clarity and validity of some, the most important results. But the truth is not only the result, but also a cognitive process (Dubovyk et al., 2020).

Some scientists (Cui, Wang \& Zhong, 2021) interpret the understanding of the text as a complex analytical-synthetic process, which ends with penetration into the deep semantics of some message. Understanding occurs on two levels - on informational-cognitive one and 
on semantic level. The researcher offers the criteria for understanding the content of the message, which are related to the processes of extracting and generating the meaning of the text (Gathercole et al., 2004). According to the scientists (Pimperton \& Nation, 2010), the main criterion of understanding is the restoration of the meaning of the original message, the construction of its internal semantic structure, which is characterized by the criteria of depth and completeness of understanding.

We think that the main criterion of semantic understanding is synthesis, the generation of new meaning, which is based on the semantic basis of the text. In the researches of psychological features of the text's comprehension by university students Wong (2017) defines integrity as the important psychological characteristic of the text, provided by the unity of two semantic plans: deep aspects (contains the basic concept of the message, communicative intention of the author) and superficial ones (reveals the concept that realizes communicative intention of the text).

According to Rezaei and Mousanezhad (2020), the internal, semantic structure of the text has three main levels: a factual level, a theoretical one and a reflexive level. The most important for deep understanding of the text is the presence in its semantic structure of the reflexive level and the distribution of information of this level in the semantic space of the message. The presence of a reflective level information in the text ensures its integrity, allows us to establish a connection between individual fragments, helps to predict the continuation of the text. Reflective information increases the reader's interest because the content of the text, and provides its distribution in the message which in a great degree allows to maintain this interest (Hogan, Adlof \& Alonzo, 2014).

Some scientists also note that the category of informativeness is realized in the cognitive, reflexive and regulatory plans of information. The reflective plan of information represents the author of the novel (a poem, a story, etc.) and is realized through subjective modality or through the range of general information (Phani Krishna et al., 2020). The regulatory plan of information represents the reader of the novel (a poem, a story, etc.) and is embodied in regulatory-anticipatory and regulatory-recipient information, the main function of which is to 
control the process of perception and understanding of the text by the reader (Falé, Costa \& Luegi, 2016).

Thus, a deep understanding of the literary text involves determining its semantic structure, supporting themes; the ratio of elements of external and internal structure helps the reader to understand the direction of the author's thoughts in the process of disclosure the theme of the text; deep semantic analysis includes consideration and correlation of ways of expressing reflexive (the analysis of stylistic and linguistic means) and regulatory plan of information (the correlation of the author's text with the reader's own thoughts, knowledge, feelings, establishing connections between them, providing deeper understanding of the text) (Cheng et al, 2016).

The comprehension of the text is a central link of reading and includes: the restoration of the meaning of the original message, which is carried out through reading operations and is manifested in the construction of the semantic structure of the text; comprehension of the information or organizing the interpretation that occurs according to the interpretive schemes of the recipient; rethinking the text, which is possible under the condition of interaction of semantic positions of the author and the reader (Ehri et al, 2001). These main results show the generation of a new meaning, and the main mechanism is the dialogical interaction of the reader with the text (Murphy, Melandri \& Bucci, 2021).

Also, understanding the text is a two-way process, which is determined, on the one hand, the structure, the complexity, the volume of the text, its objective features, and on the other hand - the individual characteristics of the reader, such as: his/her knowledge, features of thought processes, the processes which imply memory, attention, the degree of formation of skills of semantic perception of the message. Thus, the reader's mastery of a set of techniques for providing semantic analysis of the text increases the effectiveness of its understanding. Understanding of the text, on the one hand, is the subject to reach general purposes and motives of reading, and on the other hand it determines the results of understanding: on the information-cognitive level (the expansion and the replenishment of knowledge of the reader, deepening of understanding by them in future professional activity); the motivational-personal level (the formation of readers' personal 
attitude to the problems having been taught in the text, the formation of professional orientations of readers); a practical level (provides the effective organization of educational and educational-professional activities) (Bucci, Maskit \& Murphy, 2016).

Thus, the purpose of our article was to conduct the empirical study of understanding contemporary poetry by future philologists, which helps us to distinguish psycholinguistic mechanisms of such understanding. Also we'll try to assess the development of personal qualities of students who are the part of the structure of reading competence. This competence, in our opinion, will facilitate students' understanding of poetry, develop their abilities to reflect their mental states, goals and speech-thinking competence, creative imagination, richness of associations, awareness of their own experiences, the ability to in-depth analysis and commenting on poetry.

The main tasks were: to outline the range of reading interests of students, to study their attitude to poetry, reading activity, poetic creativity; to clarify empirically typical difficulties in understanding poetic works by students; to analyze the peculiarities of students' awareness of the content of the concept of "understanding of a poetic text"; to find out whether students have a desire to improve the process of understanding contemporary poetry for their own professional development. In general, these tasks have the aim of studying the reading competence of students in general and to analyze many aspects of understanding poetry in the context of their reading activity.

\section{Research Methods and Techniques}

The research was carried out using a sample method (using a questionnaire developed by us (Mykhalchuk, Ivashkevych \& Nabochuk, 2020). The purpose of the research was to assess the relevance of the research of psychological features of understanding of contemporary poetry by future philologists on the basis of questionnaires; to provide clarification of a general picture of students' awareness of contemporary poetry, their attitude to poetry as a genre, to its individual types, to different poets, poetic means; determining the personal position of the student in understanding poetry and establishing personal interest in the reflection of their skills and abilities; finding out the reason for making certain evaluative judgments. 
The methods and the procedure for conducting the research. Students were asked to answer the questionnaire (28 questions) (Mykhalchuk, Ivashkevych \& Nabochuk, 2020). At the time of providing our research, all students had completed general courses in psychology, linguistics and literary studies. The blocks of questions were formulated according to the objectives of the research. The time of doing the task was not limited. On average, students worked with the questionnaire for 20-30 minutes. In the instructions students were asked to choose the answer that suits their preferences best of all, or give their own answer to these questions.

The questionnaire actually consisted of three parts. The first block of the questionnaire included questions (1-11), which made it possible to find out readers' preferences (questions № 1,2), the specifics of independent preparation of students for literature classes (questions № 3, 4), students' inclination to poetic creativity (questions № 5), age dynamics of interest in reading poetic works (questions № 6,7), students' assessment of poetry, which is in the program of the university (question № 8), as well as the range of students' reading preferences for prose and poetry (questions 9,10), the sphere of their communicative activity in the process of exchanging impressions from the poetry having been read (question № 11).

The second part of the questionnaire (questions 12-23) made it possible to assess students' reading competence, in particular the criteria for individual selection of poetic works for reading (questions № 12, 17), the reasons for difficulties in understanding poetry (question № 13), the dependence of poetry on its subject matter, the content and the form (questions № 14, 15), thematic preferences when choosing poetry (question № 16). Much attention was paid to clarifying the essence of the concept of "understanding a poetic text" (questions № 18-23).

In order to establish the peculiarities of the content of the associative series of the word "poetry", we organized an associative experiment. It was based on the method of multiple free associations, according to which the respondent in response to the stimulus was not limited to one word, but recorded the maximum number of reactions. Many years of the experience in conducting associative tests show that only rare associations are unique, most of the answers are typical. During severe time constraints, respondents usually give the most typical 
answers, increasing the time leads to increasing in their diversity and to the emergence of unusual and even unique associations. Individual differences between students, such as gender, age, nationality and additional educational activities, were not taken into account.

The word "poetry" was chosen as a stimulus. Its associative field is characterized by a wealth of connotations behind the word and it was associated with the internal lexicon of philologists. It was important for us to see how "poetry" manifests its semantic autonomy in the minds of students, reproducing the "other reality" associated with the world around them through many associative channels.

The procedure of the research. Students were asked to write down as many associations as it was possible on the special form that the word "poetry" evokes in their mind.

The task of the analysis of associations was to find out the directions in which the subject of students' speech and thinking activity was built, to reveal deep semantic connections in the process of understanding poetry. The number of associations was considered in our research as a quantitative characteristic of the lexicon, which indicates its volume. The most important for our research is a qualitative characteristic - the indicators of originality and uniqueness of associations of future philologists (such as the distinction between typical, standard and non-standard associations).

Also we used the method of annotated reading (Illyashenko, 1980). The application of this technique involved solving the following tasks: (1) to develop the criteria to understand poetry for students; (2) to determine the levels of understanding of future philologists of poetic texts.

In order to solve the above problems the authors' methodology was used, which is based on the reception of annotated reading and written feedback from the side of two subjects. Poetry was chosen for the analysis, which was too small in volume, but represented a finished work of art, where various means of artistic expression were especially concentrated.

The empirical results of our research of understanding contemporary poetry by future philologists were presented in the repository "Social Science Research Network (SSRN)" (Mykhalchuk \& Ivashkevych, 2021). 


\section{Participants}

The research was organized on the basis of philological faculties of Rivne State University of the Humanities and The International Economic-Humanitarian University named after S. Demianchuk (t. Rivne, Ukraine) during 2020-2021 years. The study involved students of 1-2 and 3-4 courses of philological specialties of these educational institutions, a total number of students was 552 people (including 504 girls and 48 boys; among them there were 325 students of Rivne State University and 227 students of The International Economic-Humanitarian University named after S. Demianchuk).

\section{Adherence to Ethical Standards}

We've followed the ethical standards of the empirical research (we've obtained the informed consent of potential participants in the experiment to voluntarily participation in the research). Ethical principles were followed in the process of conducting the empirical research: the principle of voluntary consent; the principle of minimizing risks for participants; the principle of confidentiality; the principle of informing participants about the content of the research; the principle of mandatory documentation of the stages and the results of the research; the principle of reliability of methodical instruments of the research having been conducted; the principle of validity of research data processing.

The ethical examination of the conducted empirical research was carried out and it was approved by the Committee on Ethics of Scientific Researches of the Public Organization "National Academy of Sciences of Higher Education of Ukraine”, protocol № 5, dated from the $11^{\text {th }}$ of May, 2021.

The authors does not have any potential conflict of interests that may influence the decision to publish this article.

\section{The Results of the Research}

The aim of the first stage of the research is to update all the groups of associations on the topic of "contemporary poetry" and to conduct a comparative analysis of the language series with the 
meaning of "poetry" in the group of readers; to find out the attitude of the respondent to the concept of "poetry", expressed by means of the native language.

To achieve this goal the following tasks were solved: to determine the quantitative and qualitative characteristics of the associative field of the stimulus "poetry" by students; to find out the specifics of the semantic field and the lexical content of the associative series within the meaning of the word-stimulus "poetry"; to identify the main semantic categories of associations to the word "poetry"; to compare quantitative and qualitative indicators of the results of the statement "contemporary poetry" for the formation of control and experimental groups of students.

In the process of selecting poems for this stage of the research the method of expert evaluation was used in order to identify poets whose poetry was simple or difficult to understand. The group of experts (8 people) included: Dr. of Philology P. Kraliuk (National University "Ostrog Academy", t. Ostrog, Ukraine), Dr. of Philology E. Solovey (Institute of Literary Studies of the National Academy of Sciences of Ukraine, c. Kyiv, Ukraine), Dr. of Philology G. Vokalchuk (Rivne State University of the Humanities, t. Rivne, Ukraine); $\mathrm{PhD}$ in Philology D. Kravets (Rivne State University of the Humanities, t. Rivne, Ukraine).

The group of experts also included M. Kotsyubynska, a laureate of the Shevchenko Prize, the Institute of Literary Studies of the National Academy of Sciences of Ukraine; G. Stefanova - the actress, the teacher, the reciter; $O$. Irvanets - the poet, the novelist, the playwright, a member of the Association of Ukrainian Writers; $V$. Kanevska - she is a member of the Rivne Union of Writers.

The list proposed for experts includes Ukrainian poets of the XXXXI centuries (48 in total). This poetry is studied according to high school curricula and was selected by students in a preliminary survey. Experts were asked to put letters before the names of poets, who are especially difficult to understand, the letter " $\mathrm{D}$ ", and when the poetry is simple to understand - the letter " $\mathrm{S}$ ". A number of experts noted the reasons for such assessment of the activity of poets.

Experts' assessment of a sample of contemporary Ukrainian poets was carried out by the method of semantic differential. This method makes us possible to explore general semantic characteristics of students' speech activity. The semantic differential is usually considered 
to be a rate scale that has a special structure. In our case, we used a modification of the method proposed by Charles Osgood, which allows us to measure so-called connotative meanings, to study additional semantic and stylistic nuances that are superimposed in the main meaning of the word which is used to express emotionally expressive coloring sense.

Analyzing the results of experts' assessments, we identified four groups of poets by whom there are people whose poetry is difficult to understand:

(1) the authors whose poetry is simple (S) to understand (12 poets);

(2) the authors whose poetry is more simpler than difficult to understand $(\mathrm{SD})$ (15 poets);

(3) the authors whose poetry is more complex than easy to understand $(\mathrm{CE})$ (13 poets);

(4) the authors whose poetry is difficult to understand (D) (8 poets).

Among the poets of this group the author Andievska (1987) can be considered, according to experts, the most difficult to understand. The value of semantic differential $(0.835)$, which corresponds to the understanding of her poetry, is the highest than the other values of the differentials of the poets who made up this group.

The obtained results confirm out the opinion that how difficult it is our perception of the examples when even experienced readers, including literary critics, give different, sometimes opposite assessments of the same artistic images. The results of the expert assessment are presented in the Table 1 and on the diagram (Fig. 1).

\section{Table 1}

Experts' assessment of the distribution of groups of contemporary Ukrainian poets by the complexity of understanding of their poetry

\begin{tabular}{|c|c|c|c|c|c|c|c|}
\hline \multicolumn{2}{|c|}{$\begin{array}{l}\text { The authors whose } \\
\text { poetry is simple (S) } \\
\text { to understand }\end{array}$} & \multicolumn{2}{|c|}{$\begin{array}{l}\text { The authors whose } \\
\text { poetry is more simpler } \\
\text { than difficult to } \\
\text { understand (SD) }\end{array}$} & \multicolumn{2}{|c|}{$\begin{array}{l}\text { The authors whose } \\
\text { poetry is more } \\
\text { complex than easy } \\
\text { to understand (CE) }\end{array}$} & \multicolumn{2}{|c|}{$\begin{array}{l}\text { The authors whose } \\
\text { poetry is difficult to } \\
\text { understand (D) }\end{array}$} \\
\hline The author & Rank & The author & Rank & The author & Rank & The author & Rank \\
\hline $\begin{array}{l}\text { Ellan- } \\
\text { Blackytnyi V. }\end{array}$ & 11 & Vovk V. & 27 & Nebc & 40 & Andievska E. & 48 \\
\hline Lepkyi B. & 11 & Tychyna P. & 26 & Zabuzhko O. & 39 & Tarnavskyi Yu. & 47 \\
\hline
\end{tabular}


Psycholinguistic Mechanisms of Understanding Contemporary...

\begin{tabular}{|c|c|c|c|c|c|c|c|}
\hline Voronko P. & 10 & Zerov M. & 25 & Calynets I. & 38 & $\begin{array}{l}\text { Andruchovych } \\
\text { Yu. }\end{array}$ & 46 \\
\hline Voronyi M. & 8 & Bilotserkovets N. & 24 & Antonych B.I. & 37 & Boichuk B. & 45 \\
\hline Kostenko L. & 8 & Bazhan M. & 23 & Barka V. & 36 & Semenko M. & 44 \\
\hline Zabashta L. & 6 & Clen Yu. & 22 & Rymaruk I. & 35 & Zhadan S. & 43 \\
\hline Malyshko A. & 6 & Malkovych I. & 21 & Tsybulko V. & 34 & Stus V. & 42 \\
\hline Oles O. & 5 & Vlyzko O. & 20 & Kolomiets V. & 33 & Malaniuk Ye. & 41 \\
\hline Oliinyk B. & 1 & Drach I. & 19 & Polishuk V. & 32 & & \\
\hline Pavlychko D. & 1 & Chubai G. & 18 & Osmachka T. & 31 & & \\
\hline Symonenko V. & 1 & Phylypovych P. & 17 & Svidzinskyi V. & 30 & & \\
\hline \multirow[t]{4}{*}{ Sosiura V. } & 1 & Pluzhnyk Ye. & 16 & Iogansen $\mathrm{M}$. & 28 & & \\
\hline & & Olzhych O. & 15 & Liaturynska $\mathrm{O}$. & 28 & & \\
\hline & & Irvanets $\mathrm{O}$. & 14 & & & & \\
\hline & & Rylskyi M. & 13 & & & & \\
\hline
\end{tabular}

We've to note that the ranks are increased because of the increasing complexity of understanding poetry.

\section{Figure 1}

The distribution of poets according to the complexity of understanding their poetry according to experts' assessment

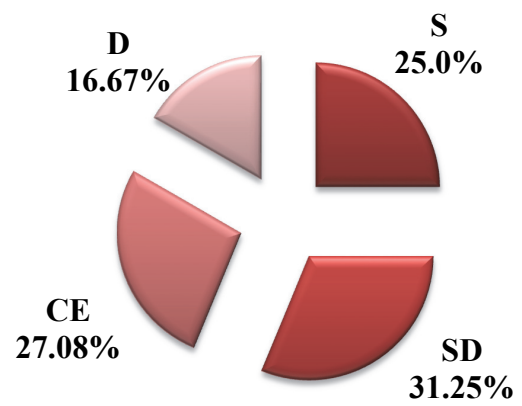

The most common reasons for the difficulty of understanding poetry, according to experts, were: surreal poetics; postmodern poetics; original and unusual worldview; deliberate outrage; intellectual beginning; high symbolism of images; high subjectivity; complex philosophical load; accumulation of worlds; mental unusualness; intertextuality; experimentalism; complex, metaphoric imagery; associative multifacetedness of semantic series; complex subtexts; guidelines for the destruction of poetic form and providing experiments with it; presence of reminiscences; complex allusions; intuitive grasp of Ukrainian archaisms; speech experiments; outdated and complex 
vocabulary; unusually large proportion of obscene vocabulary; a large number of author's innovations in poetry.

In general, experts highlighted literary, linguistic, philosophical, psychological reasons that indicate the difficulty of understanding the poetry. There was also a subjective figurative assessment of poets: "Apostle of literature", "Poet-block"; "Poet-ice", "Poet-space", "Poetconstructivist", "Poet-modernist", "Poet-futurist" and others. Some experts pointed out the importance of dialogical interaction of the reader with the author's world, such as: "The ability to combine the level of reader's knowledge with his/her own authorial experience", "To appeal to the intellectual baggage of the reader", "The need for background knowledge" and others.

Among the reasons for the simplicity of understanding poetry, experts have identified the following ones: traditional, simple imagery; visual, clear symbols; modernism with elements of traditionalism; realism with hints of romanticism; civic issues; transparent content; simplicity due to irony; clear metaphorical; populist in direction; fantastic plasticity and melody of the rhythm; light rhythmic melodies; traditional art world; problems which are close to readers; eternal themes; the author's ability to argue because of the artistic problem; the ability to use the norms of the language and speech in the process of disclosing the idea; contemporary vocabulary; clarity of expression, etc.

Selecting poems for annotated reading, we were guided by groups of poets by the difficulty of understanding their poetry, which was selected by experts. For analysis, students of philological faculty were offered one poem from each of the above groups (from the simplest to the most complex ones). Given the requirements for students, the following poetry was commented on: (1). Lina Kostenko "My madness, madness..." (Kostenko, 1989: 303). (2). Mykola Zerov "Kyiv-tradition" (Zerov, 1990: 28). (3). Igor Kalynets "Ten" (Kalynets, 2004: 288). (4). Emma Andievska "Time and its twin" (Andievska, 1987: 7). Experts in details assessed the features of the poetic style of Ukrainian authors of the XX-XXI centuries, selected by us for analysis of the poetry.

The second stage of the research has the aim conducted to determine the relevance of the problem of understanding by students of philological faculty of contemporary poetry, their reading activity and literary preferences, to identify typical difficulties in understanding poetry and to characterize their prognostic components to improve 
the process of understanding poetry for students' own professional development. Let's analyze the results having been obtained by us at the empirical research.

To find out readers' preferences and interests, students were asked the following questions: "What poetry or novels do you like to read most of all?" (question № 1), "Do you watch TV shows, read magazines about the content of the pieces of art of Ukrainian poets, prose writers?" (question № 2). The results of the analysis of the answers made us possible to state that the first place in reading preferences of students of philological faculty of the $1^{\text {st }}-4^{\text {th }}$ courses was taken by prose $(60.4 \%$ $59.7 \%$ of students). Only $18 \%$ of students (in all courses) preferred poetry. Dramatic poetry is more popular among students of the $3^{\mathrm{d}}-4^{\text {th }}$ courses $(20.8 \%)$ than those ones who are studying at the $1^{\text {st }}$ and the $2^{\mathrm{d}}$ courses $(16.0 \%)$. The lowest percentage we had when students answered other questions (for students of the $1^{\text {st }}$ and the $2^{\mathrm{d}}$ courses: folk poetry $0.9 \%$, philosophical poetry $-1.3 \%$, poetry of various genres depending on the mood $-2.8 \%$; students of the $3^{\mathrm{d}}-4^{\text {th }}$ courses preferred the poetry of psychological orientation - $1.3 \%$ ).

Future philologists of all courses show a significant level of interest $(50 \%-55.0 \%)$ according to the poetry of Ukrainian authors, prose writers through watching TV shows and reading periodicals. However, $19.0 \%-20.0 \%$ of students gave negative answers to proposed them question № 2. Some recipients $(26.0 \%-28.3 \%)$ offered their own answers, for example: "sometimes", "I read when I can", "rarely", "sometimes when I have free time", "only when I am immediately interested in this poetry", etc.

In the conditions of contemporary higher education the ability of students to acquire knowledge independently in the connection with the introduction of the competence approach provided in education plays a special role. We were interested in the specifics of preparing future philologists for discussion in literature. Question: "What is your favorite way to provide tour own activity in the process of discussion in literature?" (question № 3), "How do you prepare for discussion in literature?" (question № 4) provided the study of the level of independence of students during reading poetry. The results were such, as: $66.0 \%-70.0 \%$ of respondents tried to comprehend a poetry of their own form and the form having been explicated their own impression of what they have already read; $31.0 \%$ of students of the $1^{\text {st }}$ and the $2^{\mathrm{d}}$ 
courses and $28.6 \%$ of students of the $3^{\mathrm{d}}$ and the $4^{\text {th }}$ courses had a high level of the interpretation of the teacher's activity. Thus, a great amount of students have the awareness of the need to independently form the opinion about what they have read.

We'll argue that the most amount of students of philological faculty have a desire to choose the method of preparation for literature classes. These data are confirmed by their answers to the following question, which concerns the perception and understanding of poetry and literary criticism according to it. More than $62.7 \%$ of students of the $1^{\text {st }}$ and the $2^{\mathrm{d}}$ courses and $58.9 \%$ of respondents of the $3^{\mathrm{d}}$ and the $4^{\text {th }}$ courses only have read the poetry having been fixed on the educational program for secondary school. However, $30.9 \%-36.4 \%$ of respondents limited themselves by reading texts of literary criticism. This fact is clearly correlated with a high number of students who are guided by the teacher's interpretation in their educational and literary activity. There are students who have read only some extracts from the poetry $(4.6 \%$ of the first-year students and $2.8 \%$ of the third-fourth year students).

A great interest for poetry in the young age, as we know, is usually formed not only because of the desire to read, admire poetry, understand what the author tried to convey from the reader, but also from different attempts and a great success in writing their own poems (question № 5). Quantitative data having been obtained as the results of a survey of students of philological faculty showed that out of 552 respondents only $34.3 \%$ of them write their own poems. There is also a certain number of those respondents who write sometimes, but once have tried to write something at school (there are such $5.7 \%-13.0 \%$ of students who wanted and showed a great will to write their own poems). Such results testified a high creative potential and inclinations of contemporary youth, at least a significant part of them, to self-actualization of pupils' individual creativity, and to deeper understanding of poetry. At the same time, a large percentage of students $(52.0 \%-52.9 \%)$ have never written poetry. We can also emphasize that one of the reasons of this or that difficulties of students' understanding actualized for students the form, the content of the poetic text.

The indicators which show the age dynamics of students' interest in poetry there are original for our research. Thus, at primary and secondary classes $17.0 \%-20.0 \%$ of students liked to read poetry. In such a way in the senior classes the indicators have been increased several 
times $(36.0 \%-41.4 \%)$. More than half of all respondents $(66.0 \%-52.9 \%)$ to the question “Do you like to read poetry now?" (question № 7), gave the affirmative answer.

The students' answers concerning the identification of their favorite prose or writers are variable (question № 9). Respondents highlighted the poetry of Zagrebelnyi, Coelho, Drach, Gonchar, Bulgakov, Zuskind, Dovzhenko, Mathias, Deresh, Karpa, Akunin, Andrukhovych, Bach and others. Also students like the poets of American romanticism, such as William Cullen Bryant, John Greenleaf Whittier and others. There are the most frequent elections that take place in both groups: Zagrebelnyi (19.4\%-19.6), Kostenko (11.8\%-11.1\%), Coelho (10.5\%-16.2\%) and Andrukhovych $(3.2 \%-6.1 \%)$. Among the favorite contemporary poets (question №10) students noted: Kostenko, Zabuzhko, Pshenychna, Irvants, Andrukhovych, Andievska, Kovalchuk, Shmorhun, Smyk, Pavlychko and others. Kostenko is so called exceptional leader of students' poetic preferences, her poetry has been read by $25.6 \%$ of students of the first and the second courses. Results having been obtained by us showed that young people prefered mainly the poetry of contemporary poets and prose writers.

The purpose of the second part of the questionnaire (Mykhalchuk, Ivashkevych \& Nabochuk, 2020) had the aim to find out the features of the reading competence of future philologists. By the question "What do you focus on when choosing a poetry to read?" (question № 12) the criteria for selecting poetry for reading by students were studied. Illustrations of empirical results are given by Figure 2 .

The rest of the answers were also not frequent. We think that when choosing a poetry, some students focused their attention on the popularity of the author of the text, on the way the poet/poetess expressed his/her thoughts, the title of the poem, the author's own state of mind, intuition, mood, literary intentions and direction to which the author belonged. The results indicated that the third part of students, choosing some poetry for reading, had focused on its content.

The question № 13, concerning the reasons for the difficulties of understanding poetry, provided several possible answers. According to students, the complexity of understanding depends on: (a) a low level of general culture of the reader $(31.5 \%-30.8 \%$ of respondents); (b) the oversaturation of poetry with different artistic means: unmotivated comparisons, incomprehensible neologisms $(21.1 \%-23.0 \%$ of students); 
(c) insufficient vocabulary of the reader $(25.8 \%-18.3 \%$ of respondents);

(d) the subjective meaning of poetry $(12.0 \%-13.0 \%$ of students) and its content $(4.0 \%-1.9 \%)$. The other reasons for misunderstanding were insignificant. These reasons are: unwillingness to comprehend literature deeply, for intellectual laziness; a low level of associations, imagination; the dynamism and problems of contemporary society, which leads to a lack of time for understanding in general). It was thought that poetry, like prose, was losing its relevance due to the rapid development of the media: the Internet, cinema, and others.

Figure 2

Quantitative ratio of the directions of the selection of poetry for reading by future philologists of the $1^{\text {st }}-4^{\text {th }}$ courses

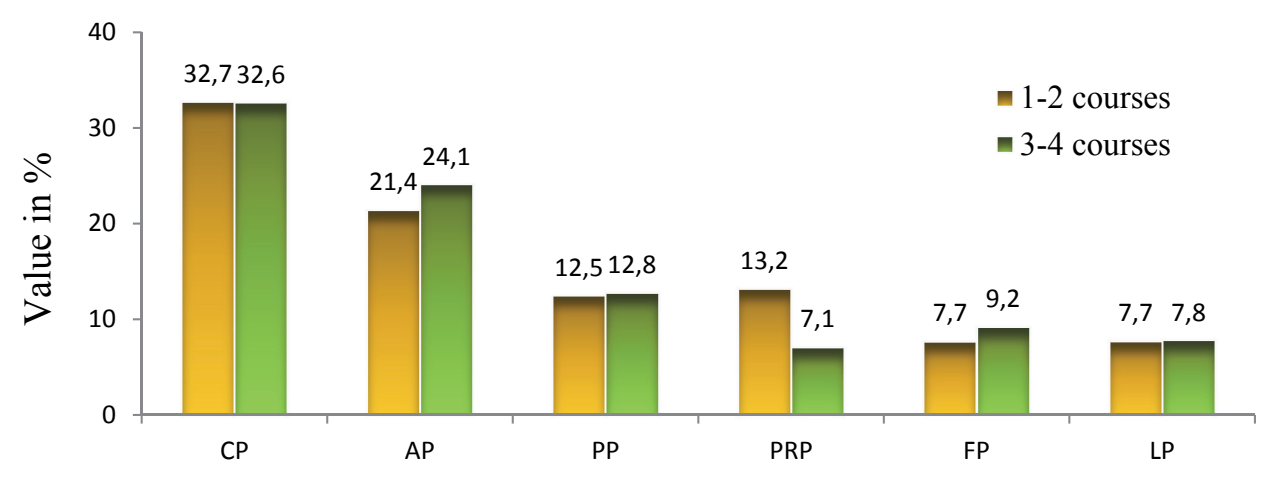

Directions of poetry selection

Symbols pointed out the selection of poetry for reading by students: $C P$ - the content of poetry; $A P$ - the actuality of poetry; PP - the popularity of poetry; PRP - positive reviews of the poetry; FP - the form of the poetry; LP - the length of the poetry.

We were interested how the opinion of students, their understanding of poetry depends on its subject (question № 14) and the form (question № 15). Thus, $54.0 \%$ of respondents of the $1^{\text {st }}$ and the $2^{\mathrm{d}}$ courses and $50.0 \%$ of students of the $3^{\mathrm{d}}$ and the $4^{\text {th }}$ courses indicate the dependence of comprehension on the form of poetry. We believe that understanding does not depend on the form $(42.0 \%-44.3 \%$ of respondents). Significantly, more higher are the indicators that state the dependence of the understanding of poetry on its subject $(84.0 \%-74.3 \%)$.

The most popular among students of philology is poetry of intimate lyrics $(39.1 \%-44.6 \%)$, humorous, satirical poetry $(19.5 \%-$ $26.4 \%)$ and poetry of moral and ethical orientations $(11.0 \%-12.4 \%)$. 
$9.1 \%-9.9 \%$ of respondents are interested in landscape poetry, $14.3 \%-$ $4.1 \%$ of students of philological faculties are inspired of texts about the historical past of different countries (question № 16). Illustrations of our results are given in Figure 3.

\section{Figure 3}

Quantitative ratio of dominant preferences of poetry by future philologists of the $1^{\text {st }}$, the $2^{d}$, the $3^{d}$ and the $4^{\text {th }}$ courses

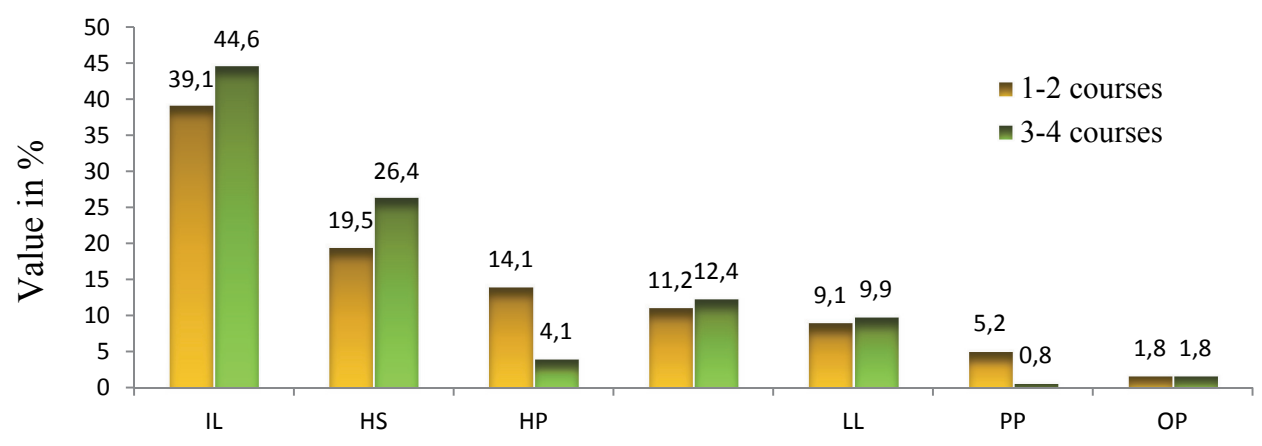

Genres of poetry

Symbols: IL - intimate lyrics; HS - humorous, satirical poetry; HP - poetry about the historical past; $M E$ - poetry of moral and ethical orientation; $L L$ - landscape lyrics; PP - patriotic poetry; OP - other poetry (poetry on other topics).

Among the poetry that students are interested most of all and poetry that encourages students greatly showed the readers what they had read many times (question № 17): the poems of Lina Kostenko $(13.1 \%-7.3 \%)$, Lesya Ukrainka $(8.0 \%-10.0 \%)$, T. Shevchenko $(8.8 \%-$ $1.8 \%)$, W. Bryant $(1.5 \%-6.4 \%)$, J. Whittier $(0.7 \%-2.7 \%)$ and others. It is worth noting a wide range of individual interests of readers, which are represented by: Skovoroda, Kotlyarevskyi, Franko, Pchilka, Saussure, Bryant, Freneau, Oles, Tychyna, Pushkin, Khayam, Whittier, Okudzhava, Yesenin, Rylskyi, Malanyuk and others.

Also important for our research there are the questions in which students highlight the problem of understanding the poetry. To the question "Which authors' poetry (of which period) do you think is the easiest to understand? Why?" respondents in general noted the poetry of these authors. We've to note that these are poems of the poets of the $\mathrm{XIX}-\mathrm{XX}$ centuries of different literary trends and currents (romanticism, modernism, realism, the Renaissance and Baroque). 
The answers express opinions about contemporary poetry, which is available in its subject matter and issues, close to the reader. Some students believe that every poet has both easy and difficult characteristics to perceive his/her poetry. The difficulty of understanding is due to the richness of artistic means, and the easiest is the simplicity of the author's idea. There are also opinions of students that the poetry of any author can be easy to understand, because it provided a deep knowledge of what it was read.

To the question: "What is the difficulty of understanding poetry?" (question № 19) students were not offered the answers, our aim was to identify individual difficulties in understanding poetry (in contrast to question № 13, which indicated possible reasons for misunderstanding of poetry). A typical answer to this question is a significant number of failures $(28.0 \%-31.4 \%)$. We believe that such data indirectly indicate that students have lack theoretical knowledge about the perception and understanding of poetic texts. This thesis is confirmed by the fact that for $17.0 \%-18.0 \%$ of respondents the difficulty of understanding poetry is the oversaturation of poetry with "incomprehensible" artistic means (epithets, metaphors, hyperboles, irony), outdated, foreign, incomprehensible words, neologisms. The rest of the answers showed that the difficulties of understanding the content of each poem depend on its subtext $(2.0 \%-7.0 \%)$, theme $(5.0 \%-4.0 \%)$, form $(2.0 \%-6.0 \%)$, ideas $(4.0 \%-4.3 \%)$, level of reader's culture $(1.0 \%-7.0 \%)$, the level of insufficient knowledge of literary studies $(3.0 \%-4.3 \%)$. These answers are supplemented by individual points of view, which have $38.0 \%-$ $18.0 \%$ of students.

At the third stage of our research a verbal-associative experiment was also organized. During the processing of the results of the associative experiment (associations with the word-stimulus "poetry"), a quantitative and qualitative analysis of the obtained data was performed. The obtained results were recorded into a Table. Words-reactions were put vertically, and the frequency of their use in this sample in absolute terms and as a percentage of the total number of responses was explicated horizontally.

As a result of primary processing, we received 1916 reactions from 152 of students. The average number of reactions per student is 12,6 , respectively. The frequency of use of all words-answers was calculated. For example, 152 students encounter the word "enthusiasm" 11 times, 
which is $0.57 \%$ of a total number of reactions in one sample. From this point of view, it is worth comparing the most frequent associations.

We have selected 20 the most frequent words-reactions based in the studied groups. The data indicate the main series of associative reactions with an average frequency of $1.3 \%$, which reflects the specifics of the information field of students of the Philological Faculty. Here is an example of a cartogram of the associative field of the word "poetry" (Figure 4).

\section{Figure 4}

The frequency of using words-reactions to the stimulus "poetry"

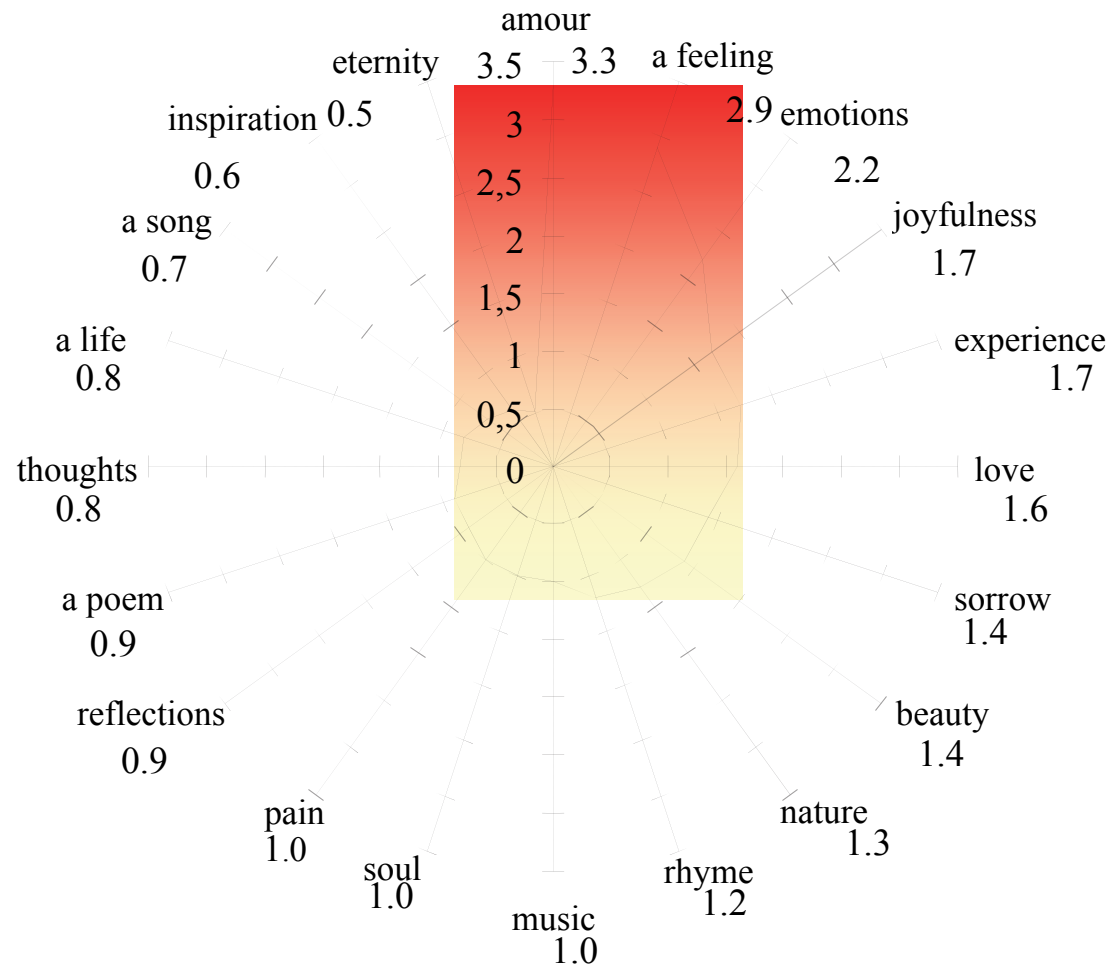

Since the respondents gave different numbers of answers, it is important to know what respondents proposed the most frequent associations. For example, the word "love" was mentioned by $40.5 \%$ of students. The second, the most frequently used word "feeling" was chosen by $35.0 \%$ of respondents. Further words-reactions "emotions" and "experiences" were chosen by $21.5 \%-27.0 \%$ of students. 
Firstly, the index of originality of answers was calculated by the formula: $Z=1 / K$, where $K$ is the frequency of a particular answer in relation to this sample. It is advisable to compare the reactions of students with the index of originality 1 . The number of such answers is 720. These are words that are used once in each sample and they are uniquely combined with the word-stimulus, for example: catharsis, truth, steadfastness, incorruptibility, nostalgia, vitality, fear because of the incomprehensible, but also the thirst for knowledge of the new, black art, grace, elitism, illusion, intimacy, flowers in the hands.

Secondly, the index of originality of each respondent was calculated by the formula: $\mathrm{N}_{\text {or }}=\Sigma \mathrm{Z} / \mathrm{x}$, where $\mathrm{N}_{\text {or }}$ is the index of originality of the student's activity; $\mathrm{x}$ is the total number of respondents' responses. The obtained data makes it possible to determine the average rate of originality of students' answers: it is 0.5 .

Thirdly, to establish the uniqueness of students' answers to this sample, such formula was used: $\mathrm{N}_{\text {un }}=1 / \mathrm{x}$, where 1 is the number of unique answers. The answer with the originality index $Z=1$ is considered as unique one. According to this position, we obtained an indicator of the uniqueness of students' answers - it is $37.6 \%$. However, analyzing reactions with a frequency of 1 , we noticed that the appearance of students does not necessarily indicate non-stereotyped, non-standard reactions. Unusual (creative, exploratory) reactions are extremely rare. The causes of such reactions will be analyzed below.

During the analysis of the obtained results, we possessed that qualitative indicators $\left(\mathrm{N}_{\mathrm{or}}, \mathrm{N}_{\mathrm{un}}\right)$ had more informative load. Quantitative indicator $\left(\mathrm{N}_{\mathrm{a}}\right.$ - denotes the number of associations); it is rather important with a great number of associations (associative fluidity), increasing on which it was emphasized the probability of obtaining original answers.

Qualitative characterization of associative pairs $(\mathrm{S}-\mathrm{R})$ having been obtained as a result of associative experiment can be performed on three interrelated levels. The first level is a deep one of relationships that exists between the content of associate words. The second one is the level of generation of the individual and stereotypical responses reactions of students. And the third level is the most general one of the organization of the associative field. The analysis of the results of associations in our research was provided at all three levels.

Thus, on the basis of a preliminary analysis of $\mathrm{S}-\mathrm{R}$ semantic relations, we made some basic observations, which were the basis 
for further identification of the following 12 groups of categories of associative reactions: cognitive ones (C), communicative reactions (Com), emotional ones (E), reactions of emphasizing content and topic categories (CTC), philosophical ones $(\mathrm{Ph})$, aesthetic reactions (Ae), categories of the activity (Ac), images ( $\mathrm{Im}$ ), reactions of sensations (S), categories of the influence (In), intertextual reactions (IR) and operational $(\mathrm{Op})$ categories.

It should be noted that this distinction is relative, as different types of relationships in some different associative pairs can be considered simultaneously from several positions. For example, the associative pair "poetry - good" can be attributed to the category of content, the theme, and can be interpreted as a category of the influence of poetry by a man. The next category "poetry - the meaning of life" belongs to the philosophical category, although it is possible to be the attribute of this pair which associates the content of categories and topics.

The obtained data give us grounds to assert that in general, according to the categorical assignment of the research, and consequently by their semantic content associations are multi-planned (Figure 5).

\section{Figure 5}

The distribution of associative categories at the stage of the experiment

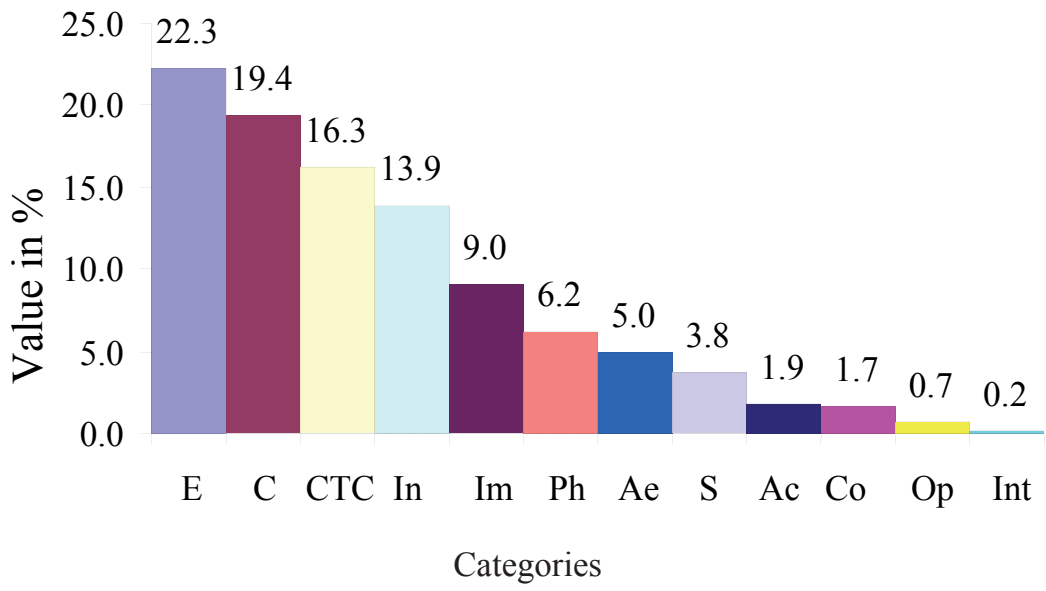

Symbols: E - emotional categories; C - cognitive categories; CTC - categories emphasizing general content and topics; In - categories of the influence on the reader; Im - categories of images and representations; $\mathrm{Ph}$ - philosophical categories; Ae - aesthetic categories; $S$ - categories of sensations; Ac - categories of the activities; Com - communicative categories; Op - operational categories; Int - intertextual categories. 
The level of generation of responses-reactions of students makes it possible to determine the differences between standard (stereotypical) and individual reactions in the conditions of associative experiment. We believe that mass reactions indicate the existence of a certain common experience in the paradigm of linguistic consciousness of the respondents as a result of reading and understanding the text.

We mean that reactions are standard when they were used with a frequency more than 2 times. Their number is 987 (51.5\%) units.

The reactions with frequency 2 constitute an intermediate (between a standard reaction and non-standard one) section of the associative field. However, by the nature of the generation in the process of associative experiment students became generally close to standard reactions. We can assume that as one of the main sample having been increased, the frequency of the most of reactions have increased. We have 209 (10.9\%) reactions with frequency of 2 . The associative field of distribution of reactions of the $4^{\text {th }}$ year students from stereotypical to individual ones is shown by Figure 6 .

\section{Figure 6}

The associative field of distribution of reactions of the $4^{\text {th }}$ year students

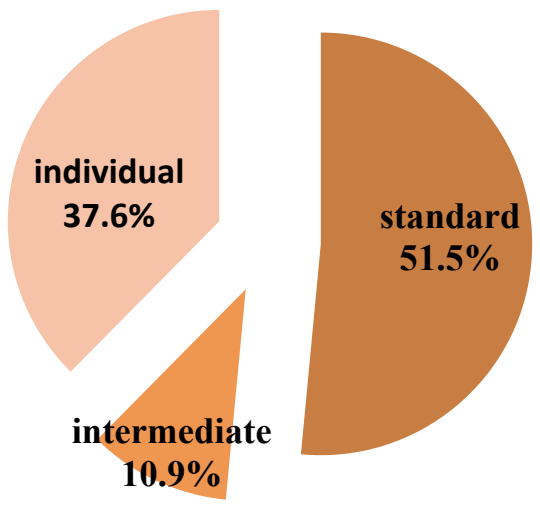

Some basic results of this article were published by us early (Mykhalchuk \& Ivashkevych, 2021). We interpret the understanding of a poetic text as a process of comprehension of explicit and implicit content by a student-philologist, finding his/her own deep meanings of a poetic text due to actualization of reflective processes of the person, creative imagination, associative thinking, personal experiences 
and so on. The process of understanding by future philologists of contemporary poetry is considered as the effective process, taking into account the person's own reading competence, the value components of his/her personality which is able "to rise" to the author of this text or even exceed it, in such a way - to understand more than the author understands himself/herself. Therefore, we believe that a future philologist understands poetry when he/she explains the content of this text through the prism of personal and professionally significant experience.

The mechanisms of understanding of novels by senior pupils (the mechanisms of: empathy, apperception, decentration, reflection, projection, anticipation, eideticism, identification, facilitation, introjection, confluence) were formulated by Mykhalchuk (2012), as well as the mechanisms of understanding the poetry were proposed by Yatsjuryk (2007) (the mechanisms of: syllabic symmetry, sound association, rhythmic ambivalence, semantic expression, phonosemantic association). We single out some special psycholinguistic mechanisms of understanding of poetic texts by students-philologists, such as:

(1) The mechanism of actualization of "emotions of form". Proposing this mechanism we based on the understanding of the concept of "emotion of form" (Vygotskyi, 2021), which the scientist called the experience that arises in the paradigm of the process of perception of artistic poetry as a whole. Such experience is a reaction to the content, which is a consequence of the integration of thoughts, the organization of a content into a certain artistic structure.

(2) The mechanism of harmonization of meaning. Harmony and beauty are the most important heuristic concepts in the field of science and art. Thus, we draw our attention to the study of the harmony of poetry. For poetry harmony is a criterion of its perfection.

We affirm the idea that the comprehension of poetry is impossible without knowledge of the epistemological reality in which the harmonious organization of the text and idiosyncrasy of the artist of the word were formed. For this purpose, a broad thematic analysis of the principles of harmonious organization of poetry and the identification of relevant trends in science are used. The structure of thematic analysis includes the principles of symmetry, additionality and relativity, the phenomenological method and the strategy of deconstruction, which are considered against the background of the structural-system approach. 
System approach allows us to consider poetry as a harmonized system. This was expressed in the present system of coordinates as a harmonious organization - a harmonious horizontal paradigm with a predominance of syntagmatic relations, a vertical systemic structure with a predominance of paradigmatic relations and depth, which is formed by the interaction of the elements of the horizontal and vertical levels.

(3) The mechanism of amplification of poetry. Analyzing the psychological meaning of the word-image in the context of a poetry, we argue that the word that passes through the poetry, absorbs the variety of semantic units included in it and becomes the equivalent of the whole text. As a result of the interpenetration of individual images, a deeper meaning is born. It is not identical to the sum of the meanings of individual images. Therefore, the mechanism of amplification contributes to the reproduction of the whole complex system of semantic connections between individual images, mediated by the appropriate organization of the content of poetry.

At the same time all linguistic elements and the elements of detachment from the linguistic units of poetry are included into the broad concept of phenomenologically given way of language existence, which correlates the meanings of linguistic units with intentional objects, as well as such more complex structures of consciousness as frames, artifacts, scenes, pictures in nonverbal forms. The depth of poetry is determined depending on the features of a figurative structure of the text (the presence and the absence of paths and figures), as well as intertextuality of poetry: language layers often activate artifacts - so called "created texts" that are revealed through the citation of the text.

(4) The mechanism of acquiring aesthetic experience. A creative process of a student of philology can be called as co-creation, because it activates the same aspects of the psyche as the activity of a writer his/her emotions, memory, imagination, various feelings, analysis and synthesis, the ability to percept the text as a whole, in its ideological and artistic sense and evaluate it, understand it in details. A novel influences only on the reader when the author gives him/her the opportunity to imagine, to supplement, to add pictures, images, figures, characters, presented by the writer from his/her personal experience. In such a way we'll note that it is from the merger, the coincidence of the experience of the creator with the experience of the reader comes so 
called "artistic truth". As a result we can see a special persuasiveness of verbal creativity, which explains the power of literature in general.

The model of understanding by future philologists of contemporary poetry is shown by us in Figure 7. The set of these mechanisms provides a deep understanding of poetry by students.

\section{Figure 7}

The model of understanding of poetry by future philologists

\section{MECHANISMS}

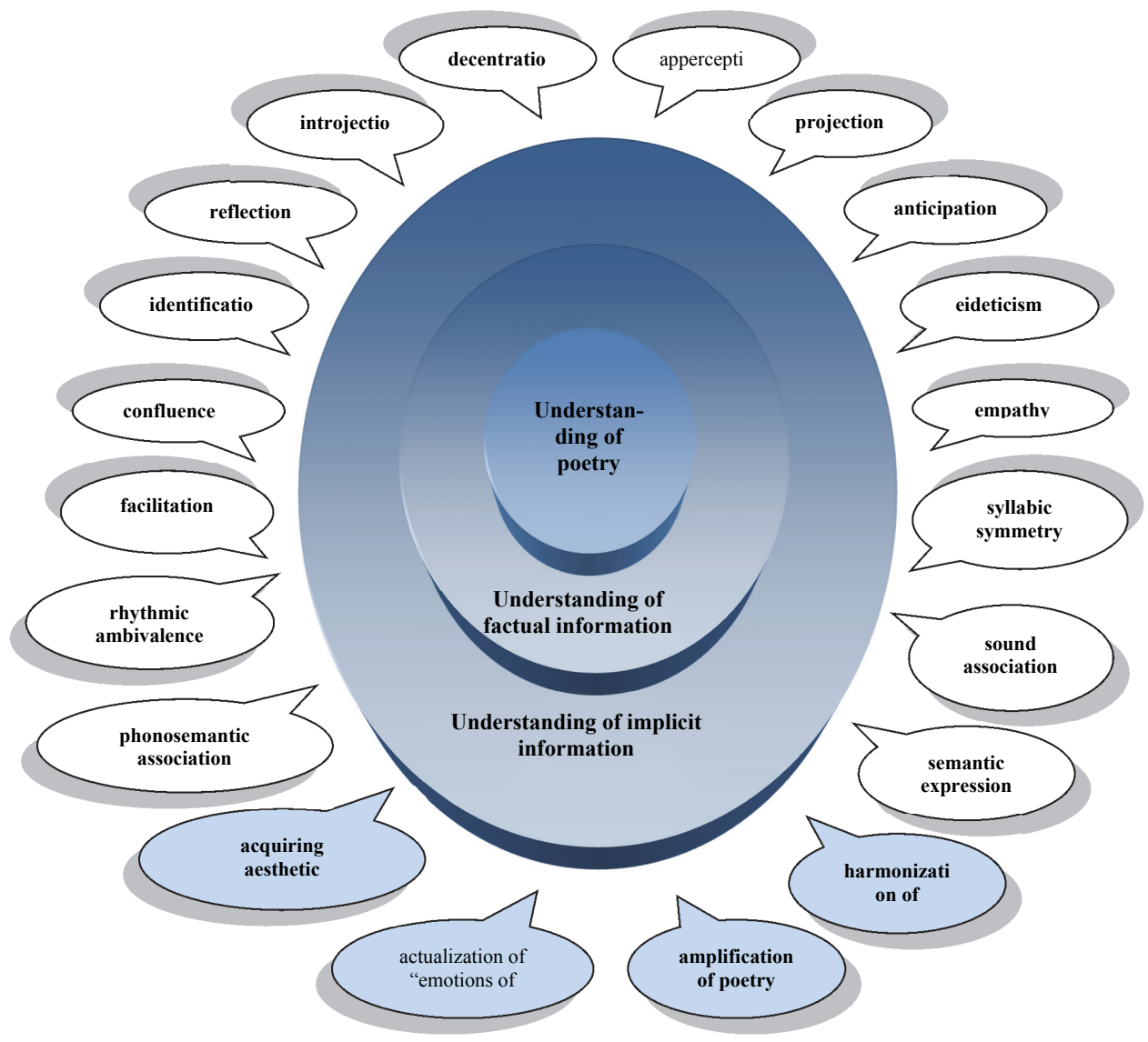

The future philologist in the process of understanding poetry focuses on the author's idea, which, in his/her opinion, should penetrate deep and adequately decipher the content of the text. To do this, the student has the necessary training, the ability to see the meaning in the 
means of poetry, to interpret adequately its stylistic means (metaphors, metonymies, epithets, comparisons, etc.) as stimulators of cognitive activity and material for constructive reflection. The information foundation of understanding is the thesaurus - a set of knowledge having been stored in the reader's memory, which is activated at the time of perception the text.

Philological training of a student involves different levels of analysis of the novel, such as: the conceptual analysis (understanding the meaning of the text from the standpoint of the author's intention, the author's worldview, his/her value system); thematic analysis (analyzing the plot); contextual analysis (manifestation of a hidden meaning that goes beyond the author's intention).

How students of philological faculties understand poetry we'll see, looking at the suggestions of future philologists according to the poetry of American romanticism. For example, Olga G., the student of the $3^{\mathrm{d}}$ course of philological faculty of Rivne State University of the Humanities: "To find out what associations and emotions J. Whittier had when he selected the most commonly used vocabulary to write his poetry, we will analyze his associations of different objects. Such analysis will allow us to determine the motives and internal impulses of the author and to identify non-linguistic semantic connections between objects and between problems that are described in the poems of J. Whittier. To prove these suggestions I'll propose a Table 2.

\section{Table 2}

Associative links of actualized lexical units in the poem "Swept by the snow" by J. Whittier

\begin{tabular}{|c|c|c|c|c|}
\hline $\begin{array}{l}\text { Winter } \\
\text { ( } 8 \text { times have } \\
\text { been used) }\end{array}$ & $\begin{array}{l}\text { Snow } \\
\text { (19 times have } \\
\text { been used) }\end{array}$ & $\begin{array}{l}\text { A fire } \\
\text { ( } 20 \text { times have } \\
\text { been used) }\end{array}$ & $\begin{array}{l}\text { A life } \\
\text { ( } 22 \text { times have } \\
\text { been used) }\end{array}$ & $\begin{array}{l}\text { A house } \\
\text { ( } 22 \text { times have } \\
\text { been used) }\end{array}$ \\
\hline $\begin{array}{l}\text { Snow, frost, } \\
\text { emptiness, } \\
\text { a family, cold, } \\
\text { the air, a wind, } \\
\text { comprehension }\end{array}$ & $\begin{array}{l}\text { A night, cold, } \\
\text { the air, a sun, } \\
\text { a light, time, } \\
\text { the Earth, } \\
\text { a friend, } \\
\text { the yard, } \\
\text { December }\end{array}$ & $\begin{array}{l}\text { Spark, heat, } \\
\text { firewood, a man, } \\
\text { creativity, energy, } \\
\text { a life, a fireplace, } \\
\text { a light, } \\
\text { the element, } \\
\text { brightness }\end{array}$ & $\begin{array}{l}\text { A year, } \\
\text { a man, people, } \\
\text { the world, } \\
\text { immortality, } \\
\text { salvation, joy, } \\
\text { value, a family }\end{array}$ & $\begin{array}{l}\text { Comfort, } \\
\text { warmth, a family, } \\
\text { a fortress, } \\
\text { support, a man, } \\
\text { the work, } \\
\text { the attention, } \\
\text { people }\end{array}$ \\
\hline
\end{tabular}

As we can see from Table 2, such associations as a sun, $a$ light, heat, a family are repeated many times in the poems written by 
J. Whittier. They are in a great degree actualized, and therefore these words express the main emotions of the author, convey his inner feelings and indicate a general idea of the poetry. A family and family warmth and a bright life are the ideal things for the author, which he described through artistic images. J. Whittier immerses himself by the memories of his childhood, compares the world of the past with the world of the future in which he has lived and lives now, by which J. Whittier understands that his childhood is full of peace, family warmth, joy and happiness which can never be returned. The author has proved that the old traditions of the people of the United States of the America are being eradicated by the new ones, which do not always meet the internal needs of the nation".

The other way to explicate psycholinguistic mechanisms of understanding of poetry by future philologists was proposed by Max D., the student of the $3^{\mathrm{d}}$ course of philological faculty of The International Economic-Humanitarian University named after S. Demianchuk (t. Rivne, Ukraine): "Analyzing the vocabulary of the poetry of J. Whittier, we can identify the main thematic fields of his poems. A large number of thematic fields is due to the genre specificity of the poetry and the scale of the issues has been raised in its paradigm.

So, thematic fields are:

(1) "The World of a Man": human, lonely, silver, girl, reason, aunt, uncle, sister, books, Read, poetry;

(2) "The World of Nature": plant, sun, hills, moon, sky, snow-storm, wind, cows, horse, cattle, sunset, night, Nature, squirrel;

(3) "The Environment": threat, cold, fire, wind, blow, roar, water, Ocean, Nature;

(4) "Childhood": childish, miracle, rhyme, free, school, cheerful, joy, luck, young, merrily, boyhood;

(5) "A Winter": December, chill, cold, snow-storm, hearth, fire, winter, firelight, wind, woods, ice-locked;

(6) "A Life": life, merry, love, live, remain, remember, dreamimg, family, legends, blessing;

(7) "A Family": son, sister, uncle, man, aunt, fireplace, household, father, boys, bed-time;

(8) "Emotions": troubled, sweet, dreams, fatal, madness, dull, great, pleasant, charity, sunset; 
(9) "Memories": boyhood, childish, gone, live on, time, change, smile, paths, hear, voice;

(10) "Calmness": calm, shade, sunset, hearth, fireplace, warm, companionship, idyllic, ease.

In general, the vocabulary of the poetry of J. Whittier creates a perfect harmony of the author's world. The poet combines majestic, solemn style and colloquial rural language in one poem. The same opinion has to be expressed by such point of view, as the word "emotions" can be described as none other lexical unit than "poetic paradigm". It is not either a formal poem, but it is neither conversational. The word "emotions" here is unique".

The next is Nataliia O., the student of the $3^{\mathrm{d}}$ course of philological faculty of Rivne State University of the Humanities: "In the poem "The first snowfall" there are all kinds of cohesion. Lexical cohesion is proposed by a large number of synonymous and antonymous links, the presence of many lexical repetitions and general motives. For example: gay, merry, cheerful, fun, pretty, laughing, glad, joyful, happy, mirth and sad, mirthless, dreary, melancholy. The leitmotif of the whole poem is the image of the home, the author in almost every stanza emphasizes the great importance of this image.

Such means of language expressions as association, personification, transference, anaphora, tautology, periphrasis, amplification are stylistic means of presentation of cohesion. These are such stylistic figures, which differentiate the poem from the usual type of the text and give an original form for the figurative expression of thoughts and feelings of a man. A lot of poems of J. Whittier have a great deal of imagery presentation throughout the entire things. Metaphors are used constantly, although similes and pun. Figurative images play the most important role in the poem, because it seems as slight resemblance of image which is used by J. Whittier in every other line of the poem. Let us briefly show some examples of the use of stylistic means in the poem.

Associations:

"Yet love will dream, and Faith will trust";

"That Life is ever lord of Death,

And Love can never lose its own!";

"Claim the first right which Nature gave";

"Shall Freedom's young apostles be";

"Presaging ill to him whom Fate..." (Whittier, 2021). 
The specificity of graphic images indicates a special artistic emphasizing of these terms. The use of a stylistic figure of transference simplifies the language, gives it the melodies of prose and brings it closer to conversational speech patterns by their intonation:

"Forgotten was the outside cold,

The bitter wind unheeded blew,

From ripening corn the pigeons flew,

The partridge drummed i' the wood, the mink

Went fishing down the river-brink" (Whittier, 2021).

To emphasize on the expression of emotional thought J. Whittier uses the stylistic figure which is called amplification:

"Oh, looking from some heavenly hill,

Or from the shade of saintly palms,

Or silver reach of river calms,

Do those large eyes behold me still?" (Whittier, 2021).

Amplification also allows the reader to prove the importance of the described phenomenon for the author himself and it is emphasized on his tense emotional state:

"We tread the paths their feet have worn,

We sit beneath their orchard trees,

We hear, like them, the hum of bees

And rustle of the bladed corn;

We turn the pages that they read,

Their written words we linger o'er..." (Whittier, 2021).

Or the next lines:

"But in the sun they cast no shade,

No voice is heard, no sign is made,

No step is on the conscious floor!" (Whittier, 2021).

In this passage J. Whittier uses as amplification so anaphora. The poet states that his relatives and friends had a long life since he had died, but the artist himself continues to live, and he is overwhelmed by both severe pain and pleasant memories of a lot of hours having been spent with his family.

With the help of paraphrase the author manages to avoid some poetic specifics. In this case, J. Whittier speaks about God, but, using paraphrases, does not indicate exactly what kind of God he means. Such 
a trope we define as the euphemism. It is a word or a verbal phrase that softens the form of the expression of such opinion, as:

"Since He who knows our need is just" (Whittier, 2021).

In such a way we assume that the main ways of comprehending the poetic text by future philologists take three semantic circles, which are dynamically superimposed on each other: "the author - a text the reader", "the perception - the experience - the understanding" and "the author - the interpreter - the addressee". The specificity and the essence of effective understanding and interpretation of a poetry by a future philologists is that the decisive factor for adequate understanding of poetry is his/her own potential of the interpreter - the subject of communication, which actualizes the true meaning of the text.

In general, text comprehension is a two-way process, determined, on the one hand, the structure, complexity, volume of the text, its objective features, and on the other hand - the individual characteristics of the reader (his/her knowledge, features of thought processes, memory, attention, the degree of formation of skills of semantic perception of the message). Thus, as it was noted above, mastering a set of techniques of semantic analysis and providing dialogical interaction with the text increases the effectiveness of its understanding by the reader.

The subject of understanding, we think, is an active communicative person with multifaceted personal qualities. Our research has shown that the psycholinguistic mechanisms of understanding are directly related to certain traits of the person, moral consciousness and worldview of the active subject. The subjective component of understanding is specified in two main groups of factors: (1) the factor of the activity of the understanding the subject, generalized in target conditions of understanding. The nature of understanding always depends on the orientation of the subject in his/her knowledge and in the process of communication in general; (2) the factor of individual-personal conditionality of understanding: the assessment by the subject of understanding of his/her own moral, volitional, emotional-communicative qualities, personal aggression, a tendency to reflection, etc.

\section{Discussion}

Exploring the understanding of contemporary newspaper text, we define understanding as a creative intellectual process, the success of 
which depends not only on the characteristics of the text, but also on the author, who proposes the program of the possibility of understanding.

Based on the results of our research, we'll describe the levels of perception of fiction by the reader, which characterize the quality of reproduction of the figurative structure of the text. A characteristic feature of the fable, the lowest level of perception is the connection of the content of a novel only with the fable, which reflects the causal links of some events and phenomena. At the same time, the content of individual details of the novel is perceived outside the semantic connections of the plot and is limited to the actualization of the reader's personal experience.

At the fragmentary level of the perception the plot connections are reproduced only by the most interconnected details, creating fragments that are the most important for the holistic perception of the novel, but the whole text is perceived only by its plot.

The next level is characterized by the perception of all the details of the novel in its semantic relationships. Each detail is a part of the ideological content and it is filled with the characteristics of the artistic image. Thus, we note that not all artistic images can be reproduced at the same level of figurative generalization and they are included into the context of the whole text. This level provides the perception of the whole content of a novel, reflects the main plot connections and does not distort the artistic idea of the text. The fragmentary-image level includes various transitional gradations between the fable and integralimage levels of the perception.

The next level is characterized by the perception of all the details of the text in its semantic relationships. Each detail is a part of the ideological content and it is filled with the characteristics of the artistic image. Thus, not all artistic images can be reproduced at the same level of figurative generalization; they have to be included into the context of the whole text. This level provides the perception of the whole content of a novel, reflects the main plot connections and does not distort the artistic idea in general. The fragmentary image level includes various transitional gradations between the fable and integral-image levels of the perception.

Thus, understanding is defined as the ability of the individual to comprehend the meaning and the significance of anything and the result having been achieved in general; understanding is caused by 
external or internal influences, the state of consciousness, which is fixed by the subject as the confidence in the adequacy of reproduced ideas and the content of different image influences. Without understanding we reach a special state of the subject which is impossible to continue communication, coordinate actions and any other conscious influences.

We agree with the opinion of scientists (Bucci, Maskit \& Murphy, 2016) according to the definition of dialogical characteristics of the text. Also we outline the following leading characteristics of a dialogical nature of a novel: the personification (the authorization, the subjectivation); the presence in the text of different views on the problems, the comparison of different positions; the addressability of the text, providing its focus on a certain group of readers, emphasizing on the author's efforts to take into account their interests, needs, the level of knowledge; the presence of gaps that seem to set the rhythm of the reader's internal dialogue; the principle of mirroring, which consists in depicting the image of the hero not directly, but by showing the reflection of his/her fate comparing it with the fates of other people. These dialogical characteristics of the text clearly indicate the direction of the author of the text on dialogical cooperation with the reader. Such characteristics are the main tasks of the author: they arise the reader's feelings and thoughts, force the reader to turn to his/her own inner world.

A necessary factor for understanding the novel is the thesaurus as a system of knowledge. Understanding of the text largely depends on the richness of the reader's thesaurus, it is pointed out by many researchers. Subjective thesaurus is a set of knowledge of the person, which is represented by linguistic and cognitive semantics, having been actualized by emotional and value formational level of the person, through which it is actual a cognitive activity of the subject. The unit of the subjective thesaurus is the word as a sign having been obtained by the subject in the process of social practice of knowledge. A cognitive system of a subjective thesaurus is represented by units in a form of concepts. We'll emphasize the attempt to study a psychological nature of the subjective thesaurus and to know the nature in its connection with the understanding, for example, of the poetic text. We found that the quantitative aspect of the thesaurus, represented by the volume of the subject's lexicon, is positively correlated with the quality of comprehension of the novel, but this pattern is not unambiguous, because 
the understanding of the text is no less influenced by another quantitative characteristics of the subjective thesaurus and the organization of the text's elements. Theoretical analysis of the content of the active part of the language thesaurus made it possible to determine the following characteristics: the degree of complexity of the content of functional and thematic fields of the thesaurus, the degree of generalization of its content, the degree of density of its thematic fields and the degree of originality of thesaurus elements. The correlation of these characteristics with the degree of adequacy of understanding of the novel showed the presence of different connections of greater density compared with the volume of a subjective thesaurus. The degree of originality of the combination of elements of the thesaurus is a characteristic that is especially valuable in the process of studying the peculiarities of understanding neoplasms of poetry.

Thus, the results of our research allowed us to point to a double connection between the understanding of the novel and the thesaurus of the person. She proves that the thesaurus is necessary for the realization of understanding, because it is a means of understanding. On the other hand, understanding "cuts off" everything that is not understood by the subject. In such a way understanding is a means of constructing a thesaurus and provides its development. Also we have expanded the idea of the thesaurus. We mean that a degree of organization of the linguistic subject's thesaurus is as well as its quantitative characteristics. It is more important for understanding the novel than the volume of the lexicon. The researcher also established the digital value of the volume of the language thesaurus of people with different levels of education, identified a critical value, below which it is impossible to reach an adequate understanding of the novel. Our research of the connection between the understanding of the novel and the quantitative characteristics of the thesaurus made us possible to analyze the subjective thesaurus in the unity of its cognitive and linguistic semantics and to quantify the understanding of the text's elements of the language thesaurus.

In such a way we developed a new approach of studying of the thesaurus because of the understanding of the novel, explored that the quantitative characteristics of the thesaurus could diagnose the level of the language and provide cognitive development of the reader. 


\section{Conclusions}

So, we proposed the original approach to the problem of psychological features of the development of the perception of the poetic form by students. We characterize the psychological conditions of perception of the poetic form by future philologists. These conditions include: mastering the language, reading technique, gaining reading experience, developing a need for correct, accurate reproduction of artistic images, reproducing the structure of the reader's emotional reaction that have been arising in the process of text reading, developing so called "poetic hearing", the ability to analyze texts, making the process of education effective, providing active attitude to the content and the form of the text (the emergence of readers' own thoughts, assessments, events and phenomena, the desire to convey this assessment for listeners), the development of internal readers' activity (enhanced the imagination and the experience of poetic images having been perceived).

We think, that the perception of poetry is the ability of the subject to operate with images, to change their position on the object under study, to keep some images in mind, to understand the mechanism of functioning - all this is such a necessary and integral component of the process of perception of poetic form, its unity with the content of the text in general. The success of improving readers' perception and understanding of the poetry depends on the activation of the latter. The factor of structures of poetic perception depends both on the texts themselves and on the age characteristics of the reader. Thus, readers focus more on direct intentions than on their own feelings and ideas about poetry, although the latter determines their different perceptions. The development of the perception of the poetic form of the reader is due to the realization of the increasing complex of emotional connections of the semantic elements of the text, and emotionality is one of the main criteria for assessing poetry. We have established a positive correlation between the cognitive and emotional evaluation of perception: the depth of understanding of the content of the poem determines the attitude to it, and a positive attitude supports a positive fixation on poetry. It has been experimentally proven that in the conditions of special education there is a qualitative shift in the perception of poetry by readers, which 
is expressed in particular in the change of the ratio of perception of form, content and design of the poetic text.

\section{References}

Adachi, P. \& Willoughby, T. (2015). Interpreting effect sizes when controlling for stability effects in longitudinal autoregressive models: Implications for psychological science. European Journal of Developmental Psychology, 12(1), 116-128. https://doi.org/10.1080/17405629.2014.963549

Alderson, J.C., Nieminen, L., \& Huhta, A. (2016). Characteristics of weak and strong readers in a foreign language. The Modern Language Journal, 100(4), 853-879. https://doi.org/10.1111/modl.12367

Andievska, E.I. (1987). Vihilii [Vigils]. Kyiv: Modernity. [in Ukrainian].

Arrington, C.N., Kulesz, P.A., Francis, D.J., Fletcher, J.M., \& Barnes, M.A. (2014). The contribution of attentional control and working memory to reading comprehension and decoding. Scientific Studies of Reading, 18(5), 325-346. https://doi.org/10.1080/10888438.2014.902461

Astle, D., \& Scerif, G. (2011). Interactions between attention and visual shortterm memory (VSTM): What can be learnt from individual and developmental differences? Neuropsychologia, 49, 1435-1445. https://doi.org/10.1016/j. neuropsychologia.2010.12.001

Berninger, V.W., \& Abbott, R.D. (2010). Listening comprehension, oral expression, reading comprehension, and written expression: Related yet unique language systems in grades 1, 3, 5, and 7. Journal of Educational Psychology, 102(3), 635-651. https://doi.org/10.1037/a0019319

Bucci, W., Maskit, B., \& Murphy, S. (2016). Connecting emotions and words: The referential process. Phenomenology and the Cognitive Sciences, 15(3), 359-383. https://doi.org/10.1007/s11097-015-9417-z

Cheng, Y., Zhang, J., Wu, X., Liu, H., \& Li, H. (2016). Cross-lagged relationships between morphological awareness and reading comprehension among Chinese children. Frontiers in Psychology, 7, 1379. https://doi.org/10.3389/ fpsyg.2016.01379

Conners, F.A. (2009). Attentional control and the simple view of reading. Reading and Writing, 22, 591-613. https://doi.org/10.1007/s11145-008-9126-X

Cui, G., Wang, Y., \& Zhong, X. (2021). The Effects of Suprasegmental Phonological Training on English Reading Comprehension: Evidence from Chinese EFL Learners. Journal of Psycholinguist Research, 50(2), 317-333. https://doi. org/10.1007/s10936-020-09743-2

Dale, R., \& Duran, N.D. (2011). The cognitive dynamics of negated sentence verification. Cognitive Science, 35(5), 983-996. https://doi.org/10.1111/j.15516709.2010.01164.x

Drigas, A., \& Karyotaki, M. (2017). Attentional control and other executive functions. International Journal of Emerging Technologies in Learning (iJET), 12(3), 219233. https://doi.org/10.3991/ijet.v12i03.6587

Dubovyk, Svitlana H., Mytnyk, Alexander Ya., Mykhalchuk, Nataliia O., Ivashkevych, Ernest E., \& Hupavtseva, Nataliia O. (2020). Preparing Future Teachers for the Development of Students' Emotional Intelligence. Journal of

(C) Mykhalchuk N., Ivashkevych E., Nohachevska I., Nabochuk A. \& Voitenko O. 175 
Intellectual Disability - Diagnosis and Treatment, 8(3), 430-436. https://doi. org/10.6000/2292-2598.2020.08.03.20

Ehri, L.C., Nunes, S.R., Willows, D.M., Schuster, B.V., Yaghoub-Zadeh, Z., \& Shanahan, T. (2001). Phonemic awareness instruction helps children learn to read: Evidence from the National Reading Panel's meta-analysis. Reading Research Quarterly, 36, 250-287. https://doi.org/10.1598/RRQ.36.3.2

El-Zawawy, A.M. (2021). On-Air Slips of the Tongue: A Psycholinguistic-Acoustic Analysis. Journal of Psycholinguist Research, 50(3), 463-505. https://doi. org/10.1007/s10936-020-09755-y

Engle, R.W. (2002). Working memory capacity as executive function. Current Directions in Psychological Science, 11, 19-23. https://doi.org/10.1111/1467-8721.00160

Falé, I., Costa, A., \& Luegi, P. (2016). Reading aloud: Eye movements and prosody. Speech Prosody, 169. https://doi.org/10.21437/SpeechProsody.2016-169

Gathercole, S.E., Pickering, S.J., Ambridge, B., \& Wearing, H. (2004). The structure of working memory from 4 to 15 years of age. Developmental Psychology, 40(2), 177-190. https://doi.org/10.1037/0012-1649.40.2.177

Greco, M., Canal, P., Bambini, V., \& Moro, A. (2020). Modulating "Surprise" with Syntax: A Study on Negative Sentences and Eye-Movement Recording. Journal of Psycholinguist Research, 49(3), 415-434. https://doi.org/10.1007/s10936-02009691-x

Hamedi, S.M., \& Pishghadam, R. (2021). Visual Attention and Lexical Involvement in L1 and L2 Word Processing: Emotional Stroop Effect. Journal of Psycholinguist Research, 50(3), 585-602. https://doi.org/10.1007/s10936-020-09709-4

Hogan, T.P., Adlof, S.M., \& Alonzo, C.N. (2014). On the importance of listening comprehension. International Journal of Speech-Language Pathology, 16(3), 199-207. https://doi.org/10.3109/17549507.2014.904441

Illyashenko, T.D. (1980). Vosprijatie i jesteticheskaja ocenka literaturnogo proizvedenija starshoklasnikami [The perception and aesthetic assessment of a novel by senior pupils]: Candidate's thesis. Kyiv [in Russian].

Kalynets, I.M. (2004). Zibrannia tvoriv [Issues]. (Vols. 1-2). (Vol. 2: Nevolnycha muza [The slave muse]). Kyiv: Fact [in Ukrainian].

Kostenko, L.V. (1989). Vybrane [Selected Issues]. Kyiv: Dnipro [in Ukrainian].

Murphy, S., Melandri, E., \& Bucci, W. (2021). The Effects of Story-Telling on Emotional Experience: An Experimental Paradigm. Journal of Psycholinguist Research, 50(1), 117-142. https://doi.org/10.1007/s10936-021-09765-4

Mykhalchuk, N., \& Bihunova, S. (2019). The verbalization of the concept of "fear" in English and Ukrainian phraseological units. Cognitive Studies | Études cognitives, 19, 11. https://doi.org/10.11649/cs.2043

Mykhalchuk, N.O. (2012). Psykholohiia chytannia ta rozuminnia literaturnykh tvoriv starshoklasnykamy [Psychology of reading and understanding of novels by high school students]. Kyiv: Print House LLC [in Ukrainian].

Mykhalchuk, N.O., Ivashkevych, E.E., \& Nabochuk, A.Yu. (2020). Anketa dlia studentiv - maibutnikh filolohiv - dlia vyiavlennia psykholinhvistychnykh kharakterystyk rozuminnia suchasnykh poetychnykh tvoriv [A Questionnaire for students - future philologists - to identify psycholinguistic characteristics of understanding contemporary poetry]: a methodical manual. Rivne: Rivne State University of the Humanities. 82 p. [in Ukrainian].

Mykhalchuk, Nataliia, \& Ivashkevych, Ernest (2021). The empirical research of understanding contemporary poetry by future philologists. Social Science 
Research Network (SSRN). https://ssrn.com/abstract=3912159 or http://dx.doi. org/10.2139/ssrn.3912159

Phani Krishna, P., Arulmozi, S., Shiva Ram, M., \& Mishra, R. Kumar (2020). Sensory Perception in Blind Bilinguals and Monolinguals. Journal of Psycholinguist Research, 49(4), 631-639. https://doi.org/10.1007/s10936-020-09689-5

Pimperton, H., \& Nation, K. (2010). Suppressing irrelevant information from working memory: Evidence for domain-specific deficits in poor comprehenders. Journal of Memory and Language, 62(4), 380-391. https://doi.org/10.1016/j.jml.2010.02.005

Rezaei, A., \& Mousanezhad Jeddi, E. (2020). The Contributions of Attentional Control Components, Phonological Awareness, and Working Memory to Reading Ability. Journal of Psycholinguist Research, 49(1), 31-40. https://doi.org/10.1007/s10936019-09669-4

Shiva Ram, M., Bhardwaj, R., \& Phani Krishna, P. (2017). Psychological pleasure in reading and visual cognition under colour luminance: A psycholinguistic approach. Psychology Cognitive Science Open Journal, 3(4), 110-115. https://doi. org/10.17140/PCSOJ-3-132.

Vygotskyi, L.S. (2021). Razvitie vysshih psihicheskih funkcij [The development of higher mental functions]. URL: http://yanko.lib.ru/books/psycho/vugotskiy-psc_ razv_chel-4-istoriya_razvitiya_vysshyh_psih_funkciy.pdf [in Russian].

Whittier, John Greenleaf (2021). Selected poems. In: Wineapple Brenda (Ed.). https:// www.loa.org/books/209-selected-poems [in English].

Wong, Y.K. (2017). Role of decoding competence in the Chinese reading comprehension development of ethnic minority students in Hong Kong. International Journal of Bilingual Education and Bilingualism, 22(8), 1016-1029. https://doi.org/10.1080/ 13670050.2017.1329273 [in English].

Wong, Y.K. (2021). Developmental Relations Between Listening and Reading Comprehension in Young Chinese Language Learners: A Longitudinal Study. Journal of Psycholinguist Research, 50(2), 261-273. https://doi.org/10.1007/ s10936-018-9619-y

Yatsjuryk, A.O. (2007). Mekhanizmy proiavu ta funktsii kreatyvnosti osobystosti [The mechanisms of manifestation and functions of the creativity of a person]. Naukovi zapysky Natsionalnoho universytetu "Ostrozka akademiia" - Scientific notes of the National University "Ostroh Academy". Series "Psychology and Pedagogy", 22, 230-234. Ostrog: Publishing House of National University Ostroh Academy.

Zerov, M.K. (1990). Tvory: v 2-kh tomakh [Issues: in 2 volumes]. (Vol. 1: Poetries. Translation). Kyiv: Dnipro [in Ukrainian].

\section{АНОТАЦІЯ}

Мета дослідження полягає у вивченні розуміння сучасної поезії майбутніми філологами, що фасилітуватиме нас до виокремлення психолінгвістичних механізмів такого розуміння.

Методи. Емпіричне дослідження проводилось із використанням методу анкетування (з використанням розробленої авторської анкети (Mykhalchuk, Ivashkevych \& Nabochuk, 2020). Цю анкету було використано для оцінки психологічної специфіки розуміння сучасної поезії майбутніми філологами. Для встановлення особливостей змісту асочіативного ряду слова “поезія" 
було організовано асоціативний експеримент. Також використано методику коментованого читання (Illyashenko, 1980). Застосування чієї техніки передбачало розв'язання таких завдань: (1) розробити критерії розуміння поезії для студентів; (2) визначити рівні розуміння майбутніми фрілологами поетичних текстів.

Результати. Виокремлено психолінгвістичні механізми розуміння поетичних текстів студентами-фрілологами, такі як: 1. Механізм актуалізації "емоцій форми". 2. Механізм гармонізації значення. 3. Механізм амплірікації поезії. 4. Механізм набуття естетичного досвіду. Доведено, що суб'єктом розуміння є людина як активний квазіспіврозмовник автора з багатогранними особистісними якостями. Суб'єктна складова розуміння конкретизується у двох основних групах факторів: (1) фактор активності суб'єкта, що узагальнений у цільових умовах самого процесу розуміння; (2) фактор індивідуально-особистісної зумовленості розуміння: оцінка суб'єктом розуміння своїх моральних, вольових, емоційно-комунікативних якостей, особистісної агресивності, здатності до рефлексії.

Висновки. Актуалізація процесів сприйняття та розуміння поезії читачами залежить від активізації емоційної сфери особистості майбутніх філологів. читачі більшою мірою зосереджуються на прямих інтенціях, ніж на власних почуттях та уявленнях про поезію, хоча остання визначає їі досить-таки різне сприйняття. Актуалізація сприйняття та розуміння поетичної форми читачем зумовлюється усвідомленням цілісного комплексу емоційних зв'язків семантичних елементів тексту, а емоційність $є$ одним з головних критеріїв оцінки поезії.

Ключові слова: психолінгвістичні механізми розуміння, "емоції форми", амплірікація поезії, набуття естетичного досвіду, суб'єктна складова розуміння, емоційно-комунікативні якості, здатність до рефлексії.

Михальчук Наталья, Ивашкевич Эрнест, Ногачевская Инна, Набочук Александр \& Войтенко Оксана. Психолингвистические механизмы понимания современной поэзии будущими филологами.

\section{АННОТАЦИЯ}

Цель исследования заключается в изучении понимания современной поэзии будущими филологами, что фасилитирует обоснование нами психолингвистических механизмов такого понимания.

Методы. Эмпирическое исследование проводилось с использованием метода анкетирования (с использованием разработанной авторской анкеты (Mykhalchuk, Ivashkevych \& Nabochuk, 2020). Эта анкета была использована для оценки психологической специфики понимания современной поэзии будущими филологами. С целью установления особенностей содержания ассоциативного ряда слова "поэзия" был проведён ассоциативный эксперимент. Также использована методика комментируемого чтения (Illyashenko, 1980).

178 (С) Михальчук Н., Івашкевич Е., Ногачевська І., Набочук О. \& Войтенко О. 
Psycholinguistic Mechanisms of Understanding Contemporary...

Применение этой техники предусматривало решение следующих задач: (1) разработать критерии понимания поэзии для студентов; (2) определить уровни понимания будущими филологами поэтических текстов.

Результаты. Выделены психолингвистические механизмы понимания поэтических текстов студентами-филологами, такие как: 1. Механизм актуализации "эмоций формы". 2. Механизм гармонизации значения. 3. Механизм амплификации поэзии. 4. Механизм приобретения эстетического опыта. Доказано, что субъектом понимания является человек как активный квазисобеседник автора с многогранными личностными качествами. Субъектная составляющая понимания конкретизируется в двух основных группах факторов: (1) фактор активности субъекта, обобщенный в целевых условиях самого прочесса понимания; (2) фрактор индивидуально-личностной обусловленности понимания: оценка субъектом понимания своих моральных, волевых, эмоционально-коммуникативных качеств, личностной агрессивности, способности к рефрлексии.

Выводы. Актуализация процессов восприятия и понимания поэзии читателями зависит от активизации эмоциональной сферы личности будущих филологов. Читатели в большей степени сосредотачиваются на прямых интенциях, чем на собственных чувствах и представлениях о поэзии, хотя последняя определяет её довольно-таки разное восприятие. Актуализация восприятия и понимания поэтической формы читателем обусловлено осознанием целостного комплекса эмоциональных связей семантических элементов текста, а эмоциональность является одним из главных критериев оценки поэзии.

Ключевые слова: психолингвистические механизмы понимания, "эмоции формы", амплификация поэзии, приобретение эстетического опыта, субъектная составляющая понимания, эмоционально-коммуникативные качества, способность к реслексии.

(C) Mykhalchuk N., Ivashkevych E., Nohachevska I., Nabochuk A. \& Voitenko O. 179 